\title{
JAK CHRONIĆ PRAWA PODSTAWOWE WLASNYCH OBYWATELI W SYTUACJI PRYMATU PRAWA UNIJNEGO? GARŚĆ REFLEKSJI NA KANWIE ORZECZNICTWA FSK I TSUE DOTYCZĄCEGO EUROPEJSKIEGO NAKAZU ARESZTOWANIA (ENA) ${ }^{1}$
}

\begin{abstract}
Streszczenie. Orzeczenie niemieckiego Federalnego Trybunału Konstytucyjnego (FSK) z 14 grudnia 2015 r. w sprawie Identitätskontrolle ma kluczowe znaczenie dla rozumienia granic możliwości ochrony krajowych praw podstawowych w Unii Europejskiej. FSK de facto przeprowadził w nim kontrolę zgodności wynikającego z prawa Unii Europejskiej obowiązku bezwarunkowego wykonania Europejskiego Nakazu Aresztowania (ENA) z konstytucyjnymi gwarancjami ochrony prawa do godności, ostatecznie jednak dochodząc do wniosku, że gwarancje konstytucyjne zasadniczo pokrywają się $\mathrm{z}$ unijnymi. Wydając swoje orzeczenie, choć było ono ewidentnie różne od dotychczasowego orzecznictwa TSUE na temat ENA, FSK stwierdził brak potrzeby zadania pytania prejudycjalnego. Pomimo to, w ewidentny sposób orzeczenie to wpłynęło na późniejszy rozwój orzecznictwa TSUE, przede wszystkim na wyrok w sprawie Aranyosi i Căldăraru. Ponadto wydaje się, że w znacznym stopniu wpłynęło ono także na dalszą dynamikę relacji pomiędzy krajowymi sądami konstytucyjnymi a TSUE w zakresie ochrony praw podstawowych. Tym samym można nawet posunąć się do stwierdzenia, że ma ono kluczowe znaczenie dla zrozumienia dynamiki procesu dialogu sądowego wewnątrz UE.
\end{abstract}

Słowa kluczowe: tożsamość konstytucyjna, kontrola tożsamości, dialog międzysądowy, prawa podstawowe, system multicentryczny.

\section{WSTEP}

Przedmiotem niniejszego tekstu będzie refleksja na temat tego, w jaki sposób sądy krajowe mogą starać się zagwarantować poziom ochrony praw podstawowych wymagany przez konstytucje krajowe w unijnym wielopoziomowym systemie prawa. Za główny punkt odniesienia dla rozważań posłuży postanowienie Federalnego Sądu Konstytucyjnego (FSK) 2 BvR 2735/14 z 14 grudnia 2015 r. $^{2}$ (postanowienie Identitätskontrolle) ${ }^{3}$ dotyczące zgodności mechanizmu

*Uniwersytet Łódzki, Katedra Europejskiego Prawa Konstytucyjnego, bartosz.soloch@ gmail.com

${ }^{1}$ Poglądy wyrażone w artykule należy traktować jako prywatne poglądy autora.

${ }^{2}$ Orzeczenie dostępne jest na oficjalnej stronie FSK, https://www.bundesverfassungsgericht.de.

${ }^{3}$ Należy podkreślić, że z jednej strony wyrok nie doczekał się dogłębnej analizy w literaturze polskiej, z drugiej, jak się wydaje, funkcjonuje jako sztandarowy przykład orzecznictwa krajowego 
Europejskiego Nakazu Aresztowania (ENA) z wynikającą z niemieckiej konstytucji zasadą uzależnienia wymierzenia kary od indywidualnie dowiedzionej winy. Powyższe orzeczenie należy uznać za niezwykle interesujące z co najmniej kilku względów. Po pierwsze, jak się wydaje, był to pierwszy przypadek orzeczenia krajowego sądu konstytucyjnego, w którym, przynajmniej w pewnym zakresie, uczyniono użytek z przysłowiowej wiszącej na ścianie strzelby, tj. kontroli zgodności regulacji unijnych z krajowymi prawami podstawowymi wchodzącymi w zakres tożsamości konstytucyjnej. Po wtóre, interesujące może być z jednej strony prześledzenie, w jaki sposób wspomniane orzeczenie mogło wpłynąć na wyrok Trybunału Sprawiedliwości Unii Europejskiej (TSUE) z 5 kwietnia 2016 r. w połączonych sprawach C-404/15 Aranyosi i Căldăraru ${ }^{4}$, z drugiej umiejscowienie go w szerszym kontekście dialogu sądowego prowadzonego pomiędzy FSK a TSUE. Wreszcie owocna może być refleksja nad jego znaczeniem dla innych państw członkowskich UE, w tym Rzeczypospolitej Polskiej. Struktura tekstu będzie podporządkowana zarysowanemu wyżej przedstawieniu problemu.

Wydaje się, że postanowienie Identitätskontrolle stanowi przykład udanej ochrony krajowej tożsamości konstytucyjnej. FSK udało się, swoją asertywną postawą, wymóc na TSUE korektę jego wcześniejszego orzecznictwa i „rozszczelnienie" systemu opartego na wzajemnym zaufaniu pomiędzy państwami członkowskimi; jednocześnie jednak FSK w kolejnych orzeczeniach nie doprowadził do rezygnacji przez niemieckie sądy z automatyzmu działania ENA. Ponadto sam FSK nie zrezygnował z dalszego zadawania pytań prejudycjalnych w kontrowersyjnych sprawach. Wreszcie, jak się wydaje, wyrok FSK wpłynął zarówno na zwiększenie gotowości do dialogu po stronie sądów konstytucyjnych, jak również samego TSUE, co może mieć dalekosiężne konsekwencje dla funkcjonowania systemu sądowego UE.

\section{OMÓWIENIE POSTANOWIENIA FSK 2 BVR 2735/14 Z 15 GRUDNIA 2015 R.}

Postanowienie FSK Identitätskontrolle dotyczy skargi konstytucyjnej skierowanej przez obywatela amerykańskiego (R.) przeciwko postanowieniu Wyższego Sądu Krajowego (Oberlandesgericht) w Düsseldorfie ${ }^{5}$, który stwierdził wykonalność ENA wystawionego przeciwko skarżącemu przez prokuraturę przy Sądzie Apelacyjnym we Florencji. W jej efekcie FSK stwierdził, że wykonanie ENA w sytuacji, w której został on skazany zaocznie przy pozbawieniu realnych gwarancji prawa do obrony, byłoby sprzeczne z prawami podstawowymi zawartymi

odnoszącego się do problematyki rozgraniczenia pomiędzy krajowymi a europejskimi prawami podstawowymi (zob. przykładowo Bárd 2018, 9-10; van der Mei 2017, 884).

${ }^{4}$ Dalej: wyrok Aranyosi.

${ }^{5}$ Postanowienie Wyższego Sądu Krajowego w Düsseldorfie z 7 listopada 2014 w sprawie III - 3 Ausl 108/14. 
w UZ RFN. Dochodząc do wniosku, że w takiej sytuacji sądy niemieckie miałyby obowiązek niestosowania prawa UE, ostatecznie jednak uznał, że nie jest konieczne sięganie po aż tak drastyczne środki, ponieważ w takiej sytuacji wykonaniu ENA na przeszkodzie stoją również unijne prawa podstawowe.

Sąd Apelacyjny we Florencji skazał skarżącego zaocznie na 30 lat więzienia za udział w zorganizowanej grupie przestępczej. $Z$ materiałów przekazanych przez florencką prokuraturę wynikało, że w odróżnieniu od postępowania pierwszoinstancyjnego, w przypadku postępowania o uchylenie wyroku zaocznego włoska procedura karna przewidywała jedynie ograniczone środki odwoławcze (m.in. poważnych ograniczeń doznawały możliwości przedstawiania nowych dowodów). Ponadto z otrzymanych akt nie wynikało, jakoby R. był świadom toczącego się przeciwko niemu zaocznie postępowania, jak również aby był on reprezentowany przed sądem włoskim przez profesjonalnego pełnomocnika.

Skarżący podniósł w swojej skardze konstytucyjnej trzy zarzuty: (i) zarzut naruszenia prawa do obrony wynikającego $\mathrm{z}$ art. $1^{6}$, art. 2 ust. $1 \mathrm{i}$ ust. $2 \mathrm{zd} .2^{7}$, art. $3^{8}$ i art. 103 ust. $1^{9}$ Ustawy Zasadniczej Republiki Federalnej Niemiec ${ }^{10}$; (ii) zarzut naruszenia prawa do rzetelnego procesu (art. 2 ust. $1 \mathrm{w}$ zw. z art. 20 ust. $3^{11}$ UZ RFN i art. 6 ust. 3 Konwencji o ochronie praw człowieka i podstawowych wolności otwartej do podpisu w Rzymie 4 listopada 1950 r. ze zm. (EKPC) oraz (iii) zarzut naruszenia minimalnego standardu prawnomiędzynarodowego $\mathrm{z}$ art. $25 \mathrm{UZ} \mathrm{RFN}^{12} \mathrm{i}$ art. 6 ust. 3 EKPC.

Badając zarzuty podniesione przez skarżącego, FSK w pierwszej kolejności stwierdził, że w wypadku uprawdopodobnienia naruszenia prawa do obrony,

${ }^{6}$ Art. 1 UZ RFN: (1) Godność człowieka jest nienaruszalna. Jej poszanowanie i ochrona jest obowiązkiem wszelkich władz państwowych. (2) Naród niemiecki uznaje dlatego nienaruszalne i niezbywalne prawa człowieka za podstawę każdej społeczności ludzkiej, pokoju i sprawiedliwości na świecie. (3) Poniższe prawa podstawowe jako prawa bezpośrednio obowiązujące wiążą ustawodawstwo, władzę wykonawczą i wymiar sprawiedliwości.

${ }^{7}$ Art. 2 UZ RFN: (1) Każdy ma prawo do swobodnego rozwoju swojej osobowości, o ile nie narusza praw innych i nie wykracza przeciwko porządkowi konstytucyjnemu lub nakazom moralnym. (2) [...] Wolność osobista jest nienaruszalna [...].

${ }^{8}$ Art. 3 UZ RFN: (1) Wszyscy ludzie są równi wobec prawa. (2) Mężczyźni i kobiety są równouprawnieni. Państwo wspiera rzeczywistą realizację równouprawnienia kobiet i mężczyzn oraz wpływa na usuwanie istniejących różnic. (3) Nikt nie może być dyskryminowany lub uprzywilejowany ze względu na płeć, urodzenie, rasę, język, ojczyznę i pochodzenie, wyznanie, poglądy religijne lub polityczne. Nikt nie może być dyskryminowany ze względu na swoją niepełnosprawność.

${ }^{9}$ Art. 103 ust. 1 UZ RFN: Każdemu przysługuje prawo do wysłuchania przez sąd.

${ }^{10}$ Grundgesetz für die Bundesrepublik Deutschland z 23.05.1949, BGBl. S 1 z późniejszymi zmianami, tłum. za: Staśkiewicz 2011 (dalej: UZ RFN).

${ }^{11}$ Art. 20 ust. 3 UZ RFN: Ustawodawstwo związane jest porządkiem konstytucyjnym, a władza wykonawcza i wymiar sprawiedliwości ustawami i prawem.

${ }^{12}$ Art. 25 UZ RFN: Ogólne zasady prawa międzynarodowego są częścią składową prawa federalnego. Mają one pierwszeństwo przed ustawami oraz tworzą prawa i obowiązki bezpośrednio dla mieszkańców terytorium Federacji. 
będącego wyrazem godności ludzkiej zapisanej w art. 1 ust. 1 UZ RFN, z racji ciężaru gatunkowego nie znajdują zastosowania wypracowane we wcześniejszym orzecznictwie ograniczenia dla kontroli aktów prawa wtórnego w ramach „kontroli tożsamości" (Identitätskontrolle, nb. 34) ${ }^{13}$.

Odnosząc się do kwestii dopuszczalności badania przez FSK zgodności aktów prawa UE z UZ RFN, FSK podkreślił wprawdzie, że zgodnie z wcześniejszym orzecznictwem, zasadą jest zapewnianie pierwszeństwa prawu UE wobec prawa krajowego wynikające z art. 23 ust. 1 UZ RFN ${ }^{14}$, zakreślającego obowiązek działania przez RFN na rzecz wzmocnienia UE. Winno to się objawiać m.in. ochroną skuteczności prawa UE (nb. 37), która wymusza także zasadnicze pierwszeństwo stosowania prawa UE wobec UZ RFN (nb. 38). W związku z tym zakres kontroli konstytucyjności powinien być ograniczony do elementów aktów władz państwowych, w których mają one pozostawione luzy decyzyjne (Gestaltungsspielraum, nb. 39). Następnie jednak FSK zwrócił uwagę, że przekroczenie granic „tożsamości konstytucyjnej” jest przypadkiem szczególnym. Wiąże się ono z przekroczeniem granic konstytucyjnego wzorca „otwartej państwowości” (Grenzen offener Staatlichkeit) i tym samym stanowi działanie bezprawne, którego nie można uprawomocniać kreatywną interpretacją prawniczą (nb. 42). Kontrola może przybrać zarówno postać testu ultra vires, jak również postać testu Solange (tożsamości konstytucyjnej), przy czym niezależnie od przyjętej formuły, konsekwencją bardzo wąsko określanych przypadków „niezdania” testu będzie niestosowanie prawa UE przez FSK. Naruszenie testu Solange stwierdzić może wyłącznie FSK, działający m.in. wskutek złożonej skargi konstytucyjnej (nb. 43). W opinii FSK kontrola tożsamości jest zgodna z unijną zasadą lojalności, ponieważ konsekwencją pozycji państw członkowskich jako panów traktatów jest pozostawienie im swobody w wyborze sposobu na zapewnienie obowiązywania i pierwszeństwa prawu UE (nb. 44). Skutkiem tego, jeśli RFN w ściśle ograniczonych przypadkach

${ }^{13}$ „Kontrola tożsamości” polega na badaniu przez FSK, czy stosowanie prawa UE nie naruszy obowiązków wynikających z przepisów UZ RFN, mających najbardziej podstawowe znaczenie dla ustroju Niemiec; chodzi tutaj o przepisy objęte tzw. klauzulą wieczności, obejmujące m.in. zasady demokracji i państwa prawnego, czy też godność ludzką, uznawaną za najbardziej fundamentalne prawo podstawowe. W odróżnieniu od „kontroli tożsamości”, kontrola ultra vires polega na badaniu przez sąd krajowy, czy organy UE nie przekroczyły kompetencji powierzonych im na mocy traktatów. Szerzej na temat pojęcia kontroli tożsamości konstytucyjnej, jego źródeł w UZ RFN i związków z prawem UE zob.: Callies 2016, 60 i n.; Bogdandy, Schill 2017.

${ }^{14}$ Art. 23 ust. 1 UZ RFN: Dla urzeczywistnienia zjednoczonej Europy Republika Federalna Niemiec współdziała w rozwoju Unii Europejskiej, która jest zobowiązana do przestrzegania zasad demokracji, państwa prawnego, socjalnego i federacyjnego oraz zasady subsydiarności, i gwarantuje ochronę praw podstawowych w swej istocie porównywalną z niniejszą Ustawą Zasadniczą. W tym celu Federacja w drodze ustawy wymagającej zgody Bundesratu może przekazywać prawa suwerenne. Dla ustanowienia Unii Europejskiej, jak również w celu zmiany jej podstaw traktatowych i analogicznych regulacji, przez które niniejsza Ustawa Zasadnicza w swojej treści zostaje zmieniona lub uzupełniona, lub umożliwia takie zmiany i uzupełnienia, obowiązuje art. 79 ust. 2 i 3. 
nie zastosuje prawa UE, nie naruszy to zasady przyjazności prawu europejskiemu wyrażonej w art. 23 ust. 1 zd. 1 UZ RFN (nb. 45). Nie będzie to stanowiło również przeszkody dla zapewnienia skuteczności prawu UE; sytuacje odmowy jego zastosowania będą bardzo rzadkie z co najmniej dwu względów: skuteczności ochrony praw jednostki zapewnianej przez prawo UE, jak również obowiązku wykonywania przez FSK kontroli tożsamości w sposób przyjazny prawu UE (nb. 46). FSK podkreślił dodatkowo, że pogląd o możliwości ograniczenia wewnątrzkrajowej skuteczności prawa UE przez krajowe konstytucje jest powszechnie akceptowany przez judykaturę państw europejskich (nb. 47). Kończąc swój wywód, FSK podkreślił, że gwarancja ochrony prawa do godności stanowi część tożsamości konstytucyjnej, która nie może podlegać relatywizacji (nb. 48-49).

W opinii FSK decyzja OLG przekraczała granice wyznaczone przez art. 1 ust. $1 \mathrm{w}$ zw. z art. 23 ust. 1 zd. 3 i art. 79 ust. $3^{15}$ UZ RFN (nb. 51). Wykonanie decyzji sądu, nakazującego wykonanie ENA wystawionego przez władze włoskie, naruszałoby stanowiącą część prawa do godności gwarancję bycia osądzonym indywidualnie w oparciu o kryterium winy (nb. 52-55), ponieważ zgodnie z niemiecką konstytucją poszukiwanie winy musi odbywać się przy realnym poszanowaniu praw podstawowych i zapewnieniu możliwości obrony (nb. 56-61). Niemieckim sądom nie wolno zaś w żaden sposób przykładać ręki do naruszania godności przez inne państwa (nb. 62). Oznacza to, że niemieckie sądy muszą badać z urzędu, czy państwa przekazania zapewnią poszanowanie godności, zachowując przy tym należytą staranność (nb. 65-66). W związku z powyższym, pomimo zasadniczej akceptacji dla stojącej u podstaw ENA zasady wzajemnego zaufania, FSK stwierdził, że może być ona podważona w indywidualnych wypadkach, podobnie jak ma to miejsce w przypadku ekstradycji na podstawie umów międzynarodowych (nb. 68). Przy badaniu, czy zachodzą przesłanki do odmowy wykonania ENA, nie wystarczy jednak ogólne stwierdzenie możliwości naruszenia praw jednostki; realne prawdopodobieństwo naruszenia prawa do godności musi wynikać z konkretnych okoliczności danego wypadku (nb. 71). Domniemanie braku naruszenia godności poprzez przekazanie do innego państwa jest szczególnie silne w przypadku państw członkowskich UE. W odniesieniu do nich istnieje bowiem szczególne domniemanie sprawności ich systemów ochrony praw człowieka, wynikające z konieczności spełniania kryteriów z art. 2 Traktatu o Unii Europejskiej (TUE) $)^{16}$ i wiążących władze publiczne postanowień Karty Praw Podstawowych (KPP) ${ }^{17}$, konkretniej jej art. 51 ust. 1 (nb. 73). Owo domniemanie może być jednak wzruszone na podstawie okoliczności faktycznych konkretnego wypadku (nb. 74-75).

${ }^{15}$ Art. 79 ust. 3 UZ RFN: Zmiana niniejszej Ustawy Zasadniczej, która naruszałaby podział Federacji na kraje związkowe, zasadnicze współdziałanie krajów w ustawodawstwie lub zasady określone w art. 1 i 20, jest niedopuszczalna (tzw. klauzula wieczności, Ewigkeitsklausel).

${ }^{16}$ Wersja skonsolidowana Traktatu o Unii Europejskiej, Dz.Urz. UE C 202/1, 26/10/2012, s. 13.

${ }^{17}$ Karta Praw Podstawowych, Dz.Urz. UE 2012 C 326/02, s. 391. 
FSK nie negował, że do decyzji ramowej o ENA z reguły odnosi się zasada pierwszeństwa prawa UE, realizowana zwłaszcza przez mechanizm wykładni zgodnej (nb. 77). W związku z tym wykonania ENA można odmówić tylko we wskazanych w decyzji ramowej wypadkach, w szczególności nie można powoływać się na krajowe prawo konstytucyjne (nb. 78$)^{18}$. Zgodnie z decyzją ramową odmówić wykonania ENA można tylko w wypadku naruszenia fundamentalnych wartości wymienionych w art. 6 ust. 1 TUE, zaś zasadą jest wzajemne zaufanie (nb. 81). FSK przypomniał również, że w sprawie Melloni ${ }^{19}$ TSUE zaznaczył, iż nie można uzależniać wykonania ENA od powtórzenia postępowania zakończonego wyrokiem zaocznym; w szczególności obowiązek taki nie wynika z art. 53 KPP (nb. 82). FSK stwierdził jednak, że powyższe nie zwalnia organów RFN z konieczności zapewnienia realizacji art. 1 ust. 3 UZ RFN, nawet wbrew prawu unijnemu (nb. 83).

Ostatecznie jednak FSK stwierdził, że w okolicznościach badanego przypadku nie było konieczne zanegowanie pierwszeństwa prawa UE, ponieważ wykonanie ENA naruszałoby także prawa podstawowe gwarantowane na poziomie unijnym (nb. 84). Zarówno historia i treść decyzji ramowej, jak również względy celowościowe (zwłaszcza wykładnia decyzji w świetle EKPC i orzecznictwa ETPC) wskazują bowiem na to, że nie miała ona na celu wyrażenia blankietowego uznania dla wydawanych przez państwa członkowskie wyroków zaocznych (nb. 86-90). FSK podkreślił, że samo prawo UE nie zezwala państwom członkowskim na partycypowanie w łamaniu praw człowieka (nb. 92), wywodząc stąd, że nie można interpretować ENA jako nakazującego łamanie wartości określonych w art. 6 ust. 1 TUE w sposób sprzeczny z treścią KPP (nb. 93-94). W odniesieniu do ENA art. 47 KPP wymaga, aby zagwarantowane środki odwoławcze były realne i efektywne, podobnie jak prawo do bycia wysłuchanym (nb. 97). W związku zaś z treścią art. 52 ust. 3 zd. 1 KPP, w opinii FSK w celu określenia standardu unijnego odnoszącego się do ENA konieczne jest odwołanie się do orzecznictwa ETPC na kanwie art. 6 EKPC (nb. 98-104). W konsekwencji FSK uznał, że KPP i EKPC w sposób jasny wymagają, aby sądy państwa goszczącego mogły zbadać, czy w wypadku przekazania nie dojdzie do naruszenia praw podstawowych i tej kompetencji sądu państwa wykonania nie można odczytywać jako zagrożenia dla spójności systemu ENA (nb. 106).

Kończąc swój wywód, FSK zwrócił uwagę, że powoduje to, iż tak dookreślone gwarancje unijne zasadniczo odpowiadają tym zawartym w art. 1 UZ RFN, w związku z czym nie ma potrzeby odwoływania się do pojęcia tożsamości konstytucyjnej, określonego w art. 4 ust. 2 zd. 1 TUE, w celu odmowy zastosowania prawa unijnego (nb. 107). Ostatecznie doprowadziło to FSK do uznania, że nie jest

${ }^{18}$ FSK odwołując się w tym punkcie do wyroku TSUE w sprawie Melloni, nie omieszkał odnotować, że hiszpański trybunał zadający pytanie jednak zaznaczył, że pozostaje on uprawniony do badania konstytucyjności prawa UE.

${ }^{19}$ Wyrok TSUE z 26 lutego 2013 r. w sprawie C-399/11 Melloni. 
dopuszczalne wydanie skazanego na podstawie ENA w sytuacji, w której naruszałoby to wartości wskazane w art. 6 TUE (nb. 108). FSK analizując z punktu widzenia powyższych zasad rozstrzygnięcie sprawy dokonane przez OLG Düsseldorf, doszedł do wniosku, że wykonanie wystawionego przez władze włoskie ENA w konkretnych okolicznościach naruszałoby prawa podstawowe R. (nb. 109-124).

W akapicie kończącym orzeczenie FSK odniósł się do kwestii ewentualnego pytania prejudycjalnego, stwierdzając, że byłoby ono zbędne, zważywszy że powyższe wnioskowanie wynika w sposób oczywisty i jednoznaczny z aktów prawa unijnego i zastosowanie znajduje doktryna acte clair (nb. 125).

\section{PODSTAWOWE ZAGADNIENIA}

\subsection{Prawo europejskie czy krajowe?}

Poruszany w orzeczeniu temat kontroli prawa UE z punktu widzenia tożsamości konstytucyjnej leży na styku prawa europejskiego i konstytucyjnego, nic więc dziwnego, że w orzeczeniu istotna rola przypada zagadnieniu związku pomiędzy obydwoma porządkami prawnymi. Jak się wydaje, oceny zastosowania przez FSK prawa UE można dokonać na dwu zasadniczych poziomach: (i) bezpośrednich odwołań do prawa Unii i (ii) znaczenia prawa UE dla dokonanej wykładni konstytucji. FSK interpretując UZ RFN, jak się wydaje, w praktyce przyznał wartościom mającym swoje źródło w prawie krajowym pierwszeństwo wobec wywodzących się z prawa UE, tym samym faktycznie ograniczając jego skuteczność.

Jeżeli chodzi o wykładnię konstytucji RFN w świetle prawa unijnego, to opisując zasady jej wykonywania, FSK zasadniczo powtarza swoje wcześniejsze orzecznictwo, także to dotyczące „kontroli tożsamości” ${ }^{20}$ Ciekawy jest sposób skonkretyzowania tych rozważań w odniesieniu do ENA; FSK dosyć szczegółowo przywołuje orzecznictwo TSUE dotyczące braku możliwości odmowy uznania ENA wskutek jego sprzeczności z krajowymi prawami podstawowymi, przy czym szczególna uwaga została poświęcona sprawie Melloni. Tym samym nie próbuje on ukryć istnienia pewnego napięcia między UZ RFN a prawem unijnym, tylko w sposób odważny pokazuje istnienie istotnych rozbieżności w orzecznictwie FSK i TSUE, zwracając uwagę, iż wynika z niego konieczność ochrony krajowych praw podstawowych. Nie zmienia to faktu, że pomimo powtarzanych sformułowań o konieczności wykładni UZ RFN w sposób przyjazny prawu UE, w ostatecznym rozrachunku FSK stawia wyraźne granice dla wykładni zgodnej, de facto odchodząc od niej. Nie wyciąga jednak z tych twierdzeń ostatecznych konsekwencji, FSK bowiem nie tyle orzeka o niemożności stosowania prawa UE sprzecznego

${ }^{20}$ Ogólne uwagi na temat kontroli tożsamości konstytucyjnej znaleźć można w: Callies 2016, $60 \mathrm{in.}$ 
z UZ RFN, ile raczej stwierdza, że ograniczenia dla automatyzmu w stosowaniu ENA, analogiczne do tych wynikających z UZ RFN, zawarte są również w prawie pierwotnym UE.

Trafność wspomnianej analizy przeprowadzonej przez FSK może jednak budzić pewne wątpliwości. Niemiecki sąd, rekonstruując standard unijny mający być podstawą do dokonania wykładni decyzji ENA zgodnej z prawem pierwotnym (w jego opinii odpowiadający treści UZ RFN w interpretacji dokonanej przez FSK), w zasadzie nie odwoływał się już do orzecznictwa TSUE dotyczącego wzajemnego zaufania w kontekście ENA. To pominięcie, choć nie musi przesądzać o niepoprawności całego wywodu, to jednak z całą pewnością czyni go niepełnym i pod znakiem zapytania stawia w szczególności twierdzenia FSK na temat braku konieczności zwrócenia się do TSUE z pytaniem prejudycjalnym.

Tym samym, jak się wydaje, FSK zdecydował się przeprowadzić zasadniczą ocenę proponowanych rozwiązań w trybie kontroli tożsamości konstytucyjnej, będącej tworem prawnego prawa konstytucyjnego (Burkhard 2016, 540), zaś późniejsza analiza prawa europejskiego miała charakter wtórny i służyła potwierdzeniu wniosków, do których prowadziło zastosowanie prawa krajowego. Powyższe działanie wydaje się w znacznej mierze logiczne - FSK bada zgodność ustaw z konstytucją (wykładaną, co prawda, co najmniej teoretycznie, w sposób przyjazny prawu europejskiemu), a nie z normami prawa UE, stąd też za w jakimś stopniu uzasadnione uznać można, że badanie zgodności z prawem Unii miało charakter niejako dodatkowy. Uwagę zwraca, że FSK nie odwołał się do pojęcia „tożsamości narodowej” $\mathrm{z}$ art. 4 ust. 2 TUE, chociażby w celu wzmocnienia argumentacji konstytucyjnej. Zamiast tego, niejako mimochodem, przytoczył dosyć problematyczne twierdzenie o uzasadnieniu mechanizmu „kontroli tożsamości” , wspólnymi tradycjami konstytucyjnymi państw członkowskich” z art. 6 ust. 3 TUE. Powyższe przemawia za uznaniem, że FSK przeprowadzając test „kontroli tożsamości”, odwoływał się zasadniczo do pojęć pochodzących z krajowego, a nie unijnego porządku prawnego.

Jak się wydaje, wybór taki był w pełni konsekwentny. Przede wszystkim odwołując się do unijnego pojęcia „tożsamości narodowej”, FSK stosowałby prawo UE $\mathrm{i}$ - wobec braku stosownego orzecznictwa - byłby zmuszony do zadania TSUE pytania prejudycjalnego, tak jak zrobił to włoski sąd konstytucyjny w sprawie Taricco II (zob. poniżej) $)^{21}$, czego w sposób ewidentny pragnął uniknąć. Jeżeli jednak wziąć pod uwagę niejasność standardu zawartego w art. 4 ust. 2 TUE, decyzja FSK wydaje się uzasadniona. Przede wszystkim niewiele było orzecznictwa TSUE odnoszącego się expressis verbis do pojęcia „tożsamości narodowej”. Pojawiało się ono się przed TSUE sporadycznie, w kontekście spraw dotyczących prawomocności ograniczeń dla swobód unijnych, takich jak sprawy

${ }^{21}$ Orzeczenie włoskiego sądu konstytucyjnego 24/2017, https://www.cortecostituzionale.it/ documenti/download/doc/recent_judgments/O_24_2017.pdf [dostęp 10.06.2018]. 
Sayn-Wittgenstein ${ }^{22}$ czy Michaniki ${ }^{23}$ (Koncewicz 2015, 203 i n.). Tym samym zasadne jest twierdzenie, że w szczególności w odniesieniu do prawa wtórnego (do którego zalicza się również ENA) TSUE nie dopracował się dotychczas choćby i bardzo ogólnych zasad ograniczania skuteczności prawa Unii ze względu na tożsamość konstytucyjną (Cloots 2015, 319 i n.). W rezultacie, zadając pytanie, FSK musiałby wykonać w pewnym sensie „krok w nieznane”, zdając się przy tym wyłącznie na dobrą wolę TSUE. Tym samym można powiedzieć, że FSK świadomie zdecydował się na przyjęcie rozwiązania niegwarantującego pełnej skuteczności prawu UE.

\subsection{Kwestia pytania prejudycjalnego}

FSK w rozstrzyganej sprawie stwierdził, że dokonana przez niego zgodna z prawem pierwotnym wykładnia Decyzji Ramowej była tak oczywista, że zastosowanie powinna znaleźć doktryna acte claire. Stwierdzenie to jest jednak trudne do zaakceptowania. W tym miejscu można pokrótce przypomnieć zasady zadawania pytań prejudycjalnych do TSUE. W pierwszej kolejności trzeba przypomnieć, że mechanizmem pytań prejudycjalnych objęte są również krajowe sądy konstytucyjne (Schima 2015, 43). Zgodnie z wyrokiem CLIFIT ${ }^{24}$, od obowiązku zadania pytania prejudycjalnego sąd, od którego orzeczenia nie przysługuje odwołanie, może odstąpić wyłącznie w dwu sytuacjach: jeżeli dana kwestia została dostatecznie opisana w orzecznictwie sądów unijnych (doktryna acte éclairé) lub też jej rozwiązanie jest jednoznaczne w świetle brzmienia unijnych przepisów (nb. 16-20). Tłem dla powyższych rozważań powinna być szczególna rola odgrywana przez pytanie prejudycjalne w systemie prawnym UE (Lenaerts, Maselis, Gutman 2014, 48 i n.). Sugerowałoby to, że FSK stosując doktrynę acte éclairé, powinien zachować znaczną powściągliwość i faktycznie wykazać, że sprawa doczekała się już gruntownego wyjaśnienia przez TSUE.

Biorąc pod uwagę powyższe rozważania, trudno uznać zbycie przez FSK kwestii konieczności zadania pytania prejudycjalnego krótkim passusem o dostatecznie jasnym uregulowaniu problematyki wykładni ENA w prawie unijnym za satysfakcjonujące. Należy podkreślić, że zarówno sformułowanie przez FSK zasad ograniczania skuteczności ENA w imię ochrony konstytucyjnych praw podstawowych, jak również dokonana przez FSK wykładnia ENA w świetle unijnych praw podstawowych były co najmniej dyskusyjne z punktu widzenia wcześniejszego orzecznictwa TSUE, przy szczególnym uwzględnieniu sprawy Melloni (Taborowski 2016). Jest to tym bardziej widoczne, jeśli wziąć pod uwagę, że FSK w swoim wywodzie na temat rzekomej oczywistości podjętego rozstrzygnięcia

\footnotetext{
${ }^{22}$ Wyrok TSUE z 22 grudnia 2010 r. w sprawie C-208/09 Sayn-Wittgenstein.

${ }^{23}$ Wyrok TSUE z 16 grudnia 2008 r. w sprawie C-213/07 Michaniki.

${ }^{24}$ Wyrok TSUE z 6 października 1982 r. w sprawie C-283/81 CLIFIT.
} 
nie odniósł się szerzej do stanowiska TSUE w sprawie ENA (choć wcześniej powoływał to orzecznictwo, wskazując na różnicę pomiędzy standardem krajowym a konstytucyjnym). Tym samym, jak się wydaje, z punktu widzenia prawa unijnego, FSK uchybił obowiązkowi zadania pytania prejudycjalnego (Nowag 2016, 1450-1451).

Można zastanowić się, dlaczego FSK zrezygnował z szansy na zadanie TSUE pytania prejudycjalnego. W świetle treści całego orzeczenia można z dużym prawdopodobieństwem przyjąć, że zrobił to w pełni świadomie. Jak się wydaje, uzasadnienia dla takiej decyzji można szukać w orzecznictwie TSUE. Przede wszystkim bezpośrednio przed orzeczeniem Identitätskontrolle TSUE przynajmniej w dwu istotnych sprawach pokazał swoją asertywną postawę wobec krajowych sądów konstytucyjnych chcących zapewnić na gruncie prawa UE poszanowanie własnych praw podstawowych (odpowiedź na pytanie hiszpańskiego trybunału konstytucyjnego udzielona przez TSUE w wyroku z 26 lutego 2013 r. w sprawie C-399/11 Melloni; odpowiedź na pytanie włoskiego sądu konstytucyjnego zadane w sprawie Taricco I, opisana poniżej). Kolejną perspektywą, w której można rozważać omawiane orzeczenie, jest perspektywa dialogu pomiędzy FSK a TSUE prowadzonego z wykorzystaniem pytań prejudycjalnych. W tym kontekście perspektywa byłaby zakreślana $\mathrm{z}$ jednej strony przez przełomowe pytanie prejudycjalne zadane przez FSK w sprawie $O M T^{25}$, na które TSUE udzielił w wyroku Gauweiler ${ }^{26}$ odpowiedzi ignorującej większość pytań i wątpliwości zgłaszanych przez FSK. W świetle powyższego decyzja o niezadaniu pytania staje się bardziej zrozumiała.

\subsection{Dialog czy konflikt?}

Gdyby próbować ująć sprawę w jednym zdaniu, kuszące byłoby stwierdzenie, że FSK de facto przeprowadził kontrolę regulacji unijnych z punktu widzenia tożsamości konstytucyjnej RFN, ubierając ją w szaty zwykłego stosowania prawa Unii Europejskiej, w postaci wykładni prawa wtórnego w świetle prawa pierwotnego, uchybiając przy tym obowiązkowi skierowania do TSUE pytania prejudycjalnego. Wydaje się jednak, że w rzeczywistości sprawa jest bardziej złożona. Przede wszystkim należy podkreślić, że problem, z którym skonfrontowany został FSK, nie był problemem urojonym, kwestia napięć pomiędzy automatyzmem ENA a prawami podstawowymi gwarantowanymi przez konstytucje państw członkowskich jest jednym z najtrudniejszych tematów interakcji pomiędzy prawem krajowym a europejskim. Przynajmniej w chwili wyrokowania przez FSK, zwłaszcza w świetle wyroku TSUE Melloni, trudno było uznać, że unijne

${ }^{25}$ Postanowienie FSK z 14 stycznia 2014 r. w sprawie 2 BvR 2728/13 OMT, dostępne na stronie https://www.bundesverfassungsgericht.de/SharedDocs/Entscheidungen/DE/2014/01/ rs20140114_2bvr272813.html.

${ }^{26}$ Wyrok TSUE z 16 czerwca 2015 r. w sprawie C-62/14 Gauweiler. 
prawa pozwalały na jego rozwiązanie w sposób zapewniający pełne poszanowanie gwarancji konstytucyjnych. Jednocześnie należy jednak podkreślić, że FSK chroniąc krajowe prawa podstawowe, wykonując przy tym niekiedy karkołomne operacje prawnicze polegające na interpretacji unijnego standardu ochrony praw podstawowych w sposób tożsamy z postanowieniami UZ RFN, cały czas starał się zachować przestrzeń do późniejszych interakcji pomiędzy prawem unijnym a prawem krajowym bez jednoczesnego naruszania unijnych reguł gry, czy to przez otwarte odrzucenie prawa unijnego jako naruszającego krajową konstytucję, czy też w drodze wymuszonego odwołania się do koncepcji traktatowej „tożsamości narodowej”. W szczególności w swoim postanowieniu FSK nie zawarł postanowień ograniczających możliwość składania przez sądy niemieckie pytań prejudycjalnych do TSUE, np. poprzez wprowadzenie proceduralnego obowiązku kierowania, w sytuacji możliwości konfliktu pomiędzy prawem konstytucyjnym a prawem UE, pytań w pierwszej kolejności do krajowego sądu konstytucyjnego. Co więcej, jak będę się starał wykazać poniżej, FSK i TSUE tę przestrzeń w pełni wykorzystały, przez co omawiany wyrok FSK może być interpretowany jako głos w ramach dialogu sądowego prowadzonego z TSUE.

\section{ORZECZENIE JAKO PRZYKLAD DIALOGU SĄDOWEGO}

W istocie, choć prima facie mogłoby się wydawać, że rezygnacja przez FSK $\mathrm{z}$ zadania pytania prejudycjalnego nie sprzyja uznaniu orzeczenia Identitätskontrolle za przejaw dialogu sądowego, to w perspektywie późniejszego orzecznictwa sądów unijnych widoczne będzie, że można je uznać za stanowiące głos w konwersacji konstytucyjnej pomiędzy FSK a TSUE. W następstwie orzeczenia FSK bowiem TSUE, nie negując zasadniczo automatycznego charakteru ENA, odszedł od restrykcyjnego orzecznictwa Melloni, dopuszczając odstąpienie od automatyzmu nakazu ENA w indywidualnych, szczególnie uzasadnionych przypadkach. W tym kontekście kluczowa rola przypada wyrokowi Aranyosi.

\subsection{Unijna reakcja na orzeczenie FSK}

Trudno nie dostrzec zbieżności czasowej pomiędzy orzeczeniem FSK a wyrokiem TSUE w sprawie Aranyosi ${ }^{27}$ (nota bene dotyczącym pytania zadanego przez sądy niemieckie). W orzeczeniu tym TSUE stwierdził, że niezależnie od treści decyzji ramowej o ENA, z prawa pierwotnego (konkretnie art. 4 KPP) wynika uprawnienie sądów państw członkowskich do kontrolowania zgodności nakazu ENA z krajowymi prawami podstawowymi w wąsko określonych sytuacjach.

${ }^{27}$ Wyrok TSUE z 5 kwietnia 2016 r. w połączonych sprawach C-404/15 Aranyosi i Căldăraru; opinia Rzecznika Generalnego Y. Bota pochodzi z 3 marca 2016 r. 
W tym celu możliwe było zastosowanie przez sąd krajowy dwuetapowego testu. W pierwszej kolejności konieczne jest stwierdzenie istnienia systemowych zagrożeń dla praw i wolności, przy czym musi być ono oparte na „obiektywnych, wiarygodnych, dokładnych i należycie zaktualizowanych danych [...], które dowodzą istnienia nieprawidłowości, czy to systemowych lub ogólnych, czy dotyczących niektórych grup osób" (nb. 89). Następnie, w wypadku stwierdzenia istnienia systemowych zagrożeń, konieczne jest, by wykonujący nakaz organ sądowy dokonał oceny w sposób konkretny i dokładny, sprawdzając, czy istnieją poważne i sprawdzone podstawy, aby uznać, że zainteresowana osoba będzie narażona na to niebezpieczeństwo (nb. 92). Należy podkreślić, że rozwiązanie to nie tylko stanowiło odejście od dotychczasowej praktyki TSUE (Ostropolski 2016), lecz także było zasadniczo sprzeczne z opinią Rzecznika Generalnego Y. Bota, opowiadającego się w sposób zdecydowany za utrzymaniem dotychczasowego restrykcyjnego stanowiska. Jak się wydaje, choć nie zostało to stwierdzone wprost ani w wyroku TSUE, ani w opinii Rzecznika, taka zmiana dotychczasowego orzecznictwa była spowodowana w pierwszym rzędzie przez stanowcze stanowisko FSK (Nowag 2016; Anagnostaras 2017). Powyższa teza zdaje się znajdować dodatkowe oparcie w okoliczności, że test zaproponowany przez TSUE w wyroku Aranyosi zasadniczo odpowiada testowi zaproponowanemu przez FSK (zob. powyżej). Częste powoływanie przez TSUE ww. orzeczenia świadczy o tym, że zaświadcza ono o faktycznej zmianie, która dokonała się w praktyce TSUE w zakresie rozumienia zasady zaufania ${ }^{28}$. Można ponadto $\mathrm{z}$ dużym prawdopodobieństwem przypuszczać, że również późniejsze orzecznictwo TSUE ograniczające automatyzm ENA, czy to ze względu na możliwość naruszenia prawa do rzetelnego procesu ${ }^{29}$, czy też naruszenie prawa do godnego traktowania przez warunki odbywania kary ${ }^{30}$, stanowi pokłosie wyroku w sprawie Aranyosi i, pośrednio, orzeczenia FSK.

Należy podkreślić, że TSUE w wyroku Aranyosi odwołał się wprost jedynie do gwarancji praw podstawowych zawartych w prawie unijnym, nie nawiązując przy tym do konstrukcji krajowej tożsamości konstytucyjnej. W istocie jednak, jak się wydaje, i na co wskazywałyby okoliczności sprawy rozstrzyganej przez FSK, sąd krajowy „,przemycił” tutaj własne prawa podstawowe pod płaszczem gwarancji unijnych. Tym samym można powiedzieć, że orzeczenie FSK de facto doprowadziło do zmiany orzecznictwa TSUE w kierunku umożliwiającym uwzględnianie krajowych praw podstawowych w zakresie szerszym, niż miało to miejsce dotychczas.

${ }^{28}$ Przykładowo zobacz orzeczenia TSUE z: 10 listopada 2016 r., C-477/16, PPU, nb. 27-28; 22 grudnia 2017 r., C-571/17 PPU, nb. 90; w odniesieniu do systemu dublińskiego wyrok TSUE z 16 lutego 2017 r., C-578/16, PPU, nb. 75.

${ }^{29}$ Wyrok TSUE z 25 lipca 2018 r. w sprawie C-216/18 LM versus Secretary of State.

${ }^{30}$ Opinia Rzecznika Sánchez-Bordona z 30 kwietnia 2019 r. w sprawie C-128/18 Dorobantu. 


\subsection{Możliwe perspektywy}

Mając na uwadze powyższe rozważania, wydaje się, że orzeczenie FSK można rozpatrywać $\mathrm{w}$ głównej mierze $\mathrm{z}$ dwu perspektyw: perspektywy sporu o granice zasady wzajemnego zaufania w kwestii wykonania ENA oraz perspektywy pytań prejudycjalnych kierowanych od FSK do TSUE. Zastosowanie obydwu prowadzić będzie do tego samego wniosku, tj. stwierdzenia, że postanowienie FSK w istocie stanowiło impuls do dalszego rozwoju dialogu sądowego pomiędzy FSK a TSUE.

\subsubsection{Perspektywa sporu o granice wzajemnego zaufania w kwestii wykonania ENA}

Pierwszą perspektywą, z której można postrzegać omawiane orzeczenie, jest perspektywa sporu o granice zasady wzajemnego zaufania w odniesieniu do ENA. Jak się wydaje, możliwe byłoby tutaj wskazanie pewnego continuum. Opowieść otwierałoby wspomniane już orzeczenie w sprawie Melloni, zasadniczo wykluczające możliwość ograniczenia zasady pierwszeństwa prawa UE ze względu na krajowe prawo konstytucyjne wydane w 2013 r. Orzeczenie Identitätskontrolle stanowiłoby z tej perspektywy skierowaną do ETPC propozycję przewartościowania wyroku w sprawie Melloni i dopuszczenia do rezygnacji z wykonania ENA w szczególnie uzasadnionych przypadkach. Z tej perspektywy wyrok TSUE w połączonych sprawach C-404/15 i C-659/15 PPU Aranyosi i Caldararu stanowiłby pozytywną odpowiedź na propozycję FSK.

Trafność takiego ujęcia problemu potwierdzałaby późniejsza praktyka FSK. Orzeczenie Identitätskontrolle było powoływane przez FSK przy późniejszych okazjach kilkakrotnie, z różnym skutkiem. Uwagę zwraca przede wszystkim postanowienie o nieprzyjęciu do rozpoznania skargi konstytucyjnej skierowanej przeciwko decyzji sądów o zastosowaniu ENA ${ }^{31}$, wbrew praktyce FSK (Hillgruber, Goos 2011, nb. 257) zawierającej obszerne uzasadnienia. Uwagę zwraca, że zostało ono wydane już po rozstrzygnięciu TSUE w sprawie Aranyosi. Z drugiej jednak strony FSK czasami wydaje postanowienia o wstrzymaniu wykonania ENA do czasu rozstrzygnięcia przez FSK skargi konstytucyjnej ${ }^{32}$. Ponadto postanowienie powoływane było również w sprawie odnoszącej się do odmowy wykonania ENA na podstawie przesłanek

${ }^{31}$ Postanowienie FSK z 6 września 2016 r. w sprawie 2 BvR 890/16, http://www.bverfg.de/ SharedDocs/Entscheidungen/DE/2016/09/rk20160906_2bvr089016.html

${ }^{32}$ Zob. postanowienie w sprawie 2 BvR 424/17 z 18 sierpnia 2017 r., http://www.bverfg.de/ SharedDocs/Entscheidungen/DE/2017/08/rk20170818_2bvr042417.html. Uwagę zwraca, że argumentacja FSK mogłaby wskazywać, iż wyrok TSUE w sprawie Aryanosi został przez FSK wykorzystany tutaj do wzmocnienia argumentacji o zgodności kontroli tożsamości z prawem unijnym. Postanowienie zabezpieczające FSK wydał także 6 maja 2016 r. w ostatecznie rozstrzygniętej negatywnie dla skarżącego sprawie 2 BVR 890/16, http://www.bverfg.de/SharedDocs/Entscheidungen/ DE/2016/05/rk20160506a_2bvr089016.html. 
przewidzianych w dyrektywie, gdzie jednak nie pojawiły się ani wątki kontroli tożsamości narodowej, ani poszerzania kognicji niemieckiego FSK ${ }^{33}$. Tym samym wydaje się, że praktyka sądu niemieckiego potwierdza, że jego celem było nie tyle definitywne przesądzenie o własnym pierwszeństwie wobec TSUE, ile raczej zaproponowanie sądowi europejskiemu poszerzenia przestrzeni dla zabezpieczenia praw podstawowych gwarantowanych w krajowym porządku konstytucyjnym.

\subsubsection{Perspektywa pytań prejudycjalnych zadawanych TSUE przez FSK}

Również jeśliby skupić się na kwestii wpływu postanowienia FSK na kwestię kierowania przez niemiecki sąd pytań prejudycjalnych do Luksemburga, to okaże się, że orzeczenie to nie zerwało kanałów komunikacji pomiędzy oboma sądami. Należy bowiem podkreślić, że po orzeczeniu w sprawie Identitätskontrolle FSK skierował do TSUE kolejne pytania prejudycjalne dotyczące zagadnienia ultra vires, konkretnie ponownego rozpatrzenia przez UE kwestii legalności programu skupu obligacji, rozstrzygniętej negatywnie w sprawie Gauweiler. Postanowieniem z 18 lipca 2017 r. BvR 859/15, FSK de facto zadał Trybunałowi ponownie te same pytania, co w sprawie Gauweiler, tym razem jednak sformułowane w znacznie bardziej ugodowy sposób (Lang 2018, 933 nn.). Abstrahując od powyższego, należy także przypomnieć, że postanowienie Identitätskontrolle nie zawierało postanowień mających na celu ograniczenie możliwości kierowania przez sądy niemieckie, również w sprawach dotyczących praw i wolności konstytucyjnych, pytań prejudycjalnych do TSUE. Tym samym omawiane orzeczenie można by rozumieć raczej jako próbę zaproponowania zmiany warunków prowadzonego z TSUE dialogu, niż jego odrzucenie.

\subsection{Ocena dzialań FSK}

Powyższe rozważania przemawiają za zasadnością rozumienia interakcji pomiędzy FSK a TSUE jako przykładu dialogu sądowego. Uwagę zwraca przede wszystkim restrykcyjne podejście FSK do późniejszych skarg konstytucyjnych skierowanych przeciwko postanowieniom o wykonaniu ENA (przy pozytywnym odnoszeniu się do orzecznictwa w sprawie Aranyosi), wskazujące na brak zamiaru podważenia zasady wzajemnego zaufania jako takiej. Także ponowne zadanie pytania prejudycjalnego przez FSK w sprawie tak wrażliwej jak związki pomiędzy granicami krajowej suwerenności a aktywnością Europejskiego Banku Centralnego, pomimo w pewnym stopniu rozczarowującej odpowiedzi na pytanie w sprawie $O M T$, przemawiałoby przeciwko uznaniu działań FSK za przejaw supremacjonizmu. Wręcz przeciwnie, można odnieść wrażenie, że skonfrontowany

${ }^{33}$ Postanowienie FSK z 9 listopada 2016 r. w sprawie 2 BvR 545/16, http://www.bverfg.de/ SharedDocs/Entscheidungen/DE/2016/11/rk20161109_2bvr054516.html 
z trudnym do zaakceptowania ograniczeniem zastosowania krajowych praw konstytucyjnych zaproponowanym przez TSUE w sprawach Taricco I i Melloni, jak również swego rodzaju brakiem empatii w sprawie Gauweiler, FSK podjął próbę wymuszenia na TSUE pewnej korekty swojego wcześniejszego stanowiska. Korekty, która została dokonana w odniesieniu do zakresu zastosowania ENA i która być może zostanie dokonana w odniesieniu do innych zadawanych przez FSK pytań prejudycjalnych. Jak się wydaje, postanowienie 2 BvR 2735/14 dostarczałoby tutaj swoistego pretekstu do poinformowania TSUE o istniejących wątpliwościach. Można by pokusić się tutaj o pewne subtelne analogie w stosunku do sprawy Görgülu, kiedy to FSK, w odpowiedzi na poważną ingerencję ETPC w krajowe orzecznictwo dotyczące wyważenia granic pomiędzy swobodą wypowiedzi i dobrami osobistymi w wyroku w sprawie Caroline, najpierw sformułował w sposób dokładny i dość zdecydowany koncepcję granic dla obowiązywania EKPC w krajowym porządku prawnym, by ostatecznie wypracować kompromisowe orzecznictwo (omówienie dialogu pomiędzy FSK a ETPC znaleźć można w: Krämer, Märten 2015).

\subsection{Poszerzenie perspektywy - inne państwa, inne sądy}

W celu możliwie pełnej oceny decyzji FSK, zasadne byłoby przedstawienie jej na tle innych rozstrzygnięć krajowych sądów konstytucyjnych i ETPC, w których próbowały one kwestionować dokonaną przez TSUE wykładnię prawa unijnego. W tym kontekście przywołane zostaną: dialog ETPC i TSUE dotyczący funkcjonowania sytemu azylowego; orzecznictwo czeskiego trybunału konstytucyjnego dotyczące kontroli ultra vires; trybunału konstytucyjnego węgierskiego dotyczące decyzji relokacyjnych i wreszcie dialog pomiędzy włoskim trybunałem konstytucyjnym a TSUE dotyczący sagi Taricco.

\subsection{Ruchome granice zaufania - dialog TSUE i ETPC na temat praw azylantów}

Relacjami pomiędzy prawami podstawowymi zawartymi w EKPC a prawem Unii co najmniej od czasów wyroku w sprawie Bosphorus rządzi zasada ekwiwalentnej ochrony, zgodnie z którą domniemywa się, że działania państw członkowskich podjęte w wykonaniu prawa UE spełniają standardy przewidziane w EKPC, w konkretnym przypadku domniemanie to może jednak zostać obalone (jak się wydaje, dobre podsumowanie dorobku orzeczniczego ETPC w tym zakresie zawiera wyrok Avotiņš versus Latvia $\left.{ }^{34}\right)$. Dziedziną, w której ETPC faktycznie pozwolił sobie na przełamanie tego domniemania, było europejskie prawo azylowe. W przełomowym wyroku M.S.S. przeciwko Belgii

${ }^{34}$ Wyrok ETPC z 23 maja 2016 r. w sprawie 17502/07 Avotiňš versus Latvia. 
i Grecji ${ }^{35}$ ETPC stwierdził, że państwa członkowskie - stosując w sposób automatyczny przepisy rozporządzenia dublińskiego o relokacji uchodźców, co doprowadziło do umieszczenia skarżącego w skrajnie niekorzystnych warunkach - naruszyły jego prawa gwarantowane w Konwencji. W odpowiedzi TSUE w swoim wyroku w sprawie N.S. versus Secretary of State ${ }^{36}$ uznał, że w wąsko określonych przypadkach możliwe jest podważenie automatyzmu wykonania decyzji o przekazaniu, jeżeli miałoby to prowadzić do naruszenia praw podstawowych osoby przekazywanej, określanych przez prawo UE. Orzecznictwo to było następnie podtrzymywane i rozwijane przez TSUE. Analizowane z tej strony orzeczenie w sprawie Aranyosi może być rozumiane jako rozszerzenie stosowania rozwiązań wypracowanych przez TSUE na gruncie interakcji z ETPC na gruncie stosowania rozporządzenia dublińskiego (Lenaerts 2017, 834 i nn. $\left.{ }^{37}\right)$.

\subsection{Prymat konstytucji - orzeczenia czeskiego i węgierskiego trybunału konstytucyjnego}

Należy podkreślić, że niektóre sądy środkowoeuropejskie w swojej praktyce orzeczniczej również nie wahały się wyciągać praktycznych konsekwencji ze sformułowanych przez ich trybunały konstytucyjne granic dla skuteczności prawa Unii. W tym kontekście, jak się wydaje, szczególnie interesujące są doświadczenia sądów czeskich i węgierskiego.

W kontekście czeskim kluczowe znaczenie ma historia tzw. Słowackich Emerytur $^{38}$, dotycząca schematu dopłat przez czeski rząd do emerytur dla obywateli zamieszkujących po podziale Czechosłowacji na terenie Czech. W czeskim orzecznictwie wykształciły się dwie paralelne linie orzecznicze, jedna - Trybunału Konstytucyjnego - oparta wyłącznie o czeską konstytucję i druga - sprzeczna z nią - oparta o prawo Unii Europejskiej, wypracowana przez czeskie sądy administracyjne współpracujące przy pomocy pytań prejudycjalnych z TSUE. Kulminacją sporu było stwierdzenie przez czeski trybunał konstytucyjny działania przez TSUE ultra vires w orzeczeniu Pl. US 5/12 z 31 stycznia 2012 r. ${ }^{39}$ Należy podkreślić, że wydając to orzeczenie, czeski trybunał konstytucyjny w żadnym momencie nie zwrócił się z pytaniem prejudycjalnym

${ }^{35}$ Wyrok ETPC z 21 stycznia 2011 r. w sprawie 30696/09 M.S.S. przeciwko Belgii i Grecji.

${ }^{36}$ Wyrok ETPC z 21 grudnia 2011 r. w sprawie C-411/10 N.S. versus Secretary of State.

${ }^{37} \mathrm{~W}$ tym kontekście warto zwrócić uwagę na swoiste sprzężenie zwrotne, orzeczenie w sprawie Aranyosi było bowiem wykorzystywane przez TSUE także jako uzasadnienie dla rozszerzania zakresu zastosowania wyjątków od automatyzmu wykonywania decyzji w sprawach azylowych. Tytułem przykładu zob. wyrok TSUE z 19 marca 2019 r. w sprawie C-163/17 Jawo.

${ }^{38}$ Omówienie sprawy Słowackich Emerytur znaleźć można w: Skomerska 2018, 165-170.

${ }^{39}$ Decyzja dostępna: https://www.usoud.cz/en/decisions/20120131-pl-us-512-slovak-pensions [dostęp 10.06.2018]. 
do TSUE. Z drugiej strony jednak, czeski sąd, po pierwsze, nie odwołał się do konstrukcji tożsamości narodowej, po drugie, jego orzeczenie raczej trudno uznać za stanowiące precedens dla późniejszych spraw, a radykalny ton orzeczenia wiązać należy w pierwszej linii z towarzyszącymi mu okolicznościami wewnątrzkrajowymi, tj. instytucjonalną rywalizacją pomiędzy czeskimi sądami administracyjnymi a trybunałem konstytucyjnym. Tym samym, mimo zawartych w nim radykalnych twierdzeń, trudno uznać to orzeczenie za brzemienne w skutki w stopniu choćby zbliżonym do orzeczenia FSK.

Odmienny jest przypadek węgierski. W orzeczeniu z 30 listopada 2016 r. w sprawie 22/2016. (XII. 5.) ${ }^{40}$ węgierski trybunał konstytucyjny badał zgodność z konstytucją węgierską Decyzji Rady 2015/1601 z 22 września 2015 r. dotyczącej przymusowej relokacji uchodźców. Sąd węgierski przeprowadził w nim kontrolę wzmiankowanej regulacji zarówno z punktu widzenia działania przez UE ultra vires, jak również naruszenia przez tę decyzję węgierskiej tożsamości konstytucyjnej, stwierdzając, że jej różne elementy naruszają obydwa testy. Należy podkreślić, że w tym celu w pkt 49 wyroku odwołał się on wprost do wyroku FSK Identitätskontrolle, jako zawierającego wskazówki co do sposobu przeprowadzania kontroli tożsamości konstytucyjnej. Co istotne, jak się wydaje, sąd węgierski w większym stopniu aniżeli niemiecki próbował wskazać na związki pomiędzy prowadzoną przez siebie kontrolą konstytucyjności a art. 4 ust. 2 TUE. Jak jednak zwracają uwagę niektórzy przedstawiciele doktryny, odwołanie do wyroku FSK może być mylące, zważywszy na kontekst sprawy - inaczej niż miało to miejsce w przypadku niemieckiego sądu, celem węgierskiego trybunału było nie tyle zwiększenie poziomu ochrony praw podstawowych, ile raczej ochrona dokonanego przez władze krajowe politycznego rozstrzygnięcia (Halmai 2017). Wydaje się jednak, że z jednej strony orzeczenie węgierskie można uznać w istocie za przynajmniej w jakimś stopniu inspirowane wyrokiem sądu niemieckiego, $\mathrm{z}$ drugiej zastosowane $\mathrm{w}$ nim rozumowanie wydaje się nadawać do stosunkowo łatwego przeniesienia na grunt ochrony krajowych praw podstawowych. Tym samym, pomimo powyższych zastrzeżeń, wydaje się ono wpisywać w logikę „horyzontalnego" dialogu sądów konstytucyjnych Europy Środkowo-Wschodniej (Golecki 2015).

\subsection{Warto rozmawiać? Pytanie prejudycjalne włoskiego Trybunału Konstytucyjnego w sprawie Taricco II}

Zasadne wydaje się również spojrzenie na włoską sagę Taricco. Kanwą dla składających się na nią spraw były dwie szczególne cechy włoskiego systemu prawnego. Zgodnie z włoską tradycją prawną, obrosłą w międzyczasie szerokim

${ }^{40}$ Orzeczenie dostępne: https://hunconcourt.hu/uploads/sites/3/2017/11/en_22_2016.pdf [dostęp 10.06.2018]. 
orzecznictwem również Trybunału Konstytucyjnego, okres przedawnienia dla przestępstw skarbowych stanowił część materialnoprawnej gwarancji określoności kary. W świetle trapiącej włoski system sądowy chronicznej przewlekłości oznaczało to w praktyce brak realizacji obowiązku skutecznego karania przestępstw podatkowych, określonego w art. 325 TFUE. W efekcie włoskie sądy stanęły przed dylematem, którym zobowiązaniom mają zapewnić pierwszeństwo - krajowym prawom oskarżonego czy prawu UE. Doprowadziło to do zadania przez włoski Trybunał Konstytucyjny pytania prejudycjalnego dotyczącego możliwości ograniczenia skuteczności art. 325 TFUE w imię ochrony krajowych praw podstawowych. W swoim wyroku Taricco $I^{41}$ TSUE odpowiedział na to pytanie negatywnie. Włoskie sądy nie były jednak usatysfakcjonowane otrzymaną odpowiedzią, w związku z czym kwestia relacji pomiędzy koniecznością efektywnej ochrony unijnych finansów publicznych a włoskimi gwarancjami konstytucyjnymi ponownie trafiła przed włoski Trybunał Konstytucyjny, który w swoim orzeczeniu 24/2017 zwrócił się do TSUE z pytaniem prejudycjalnym zawierającym prośbę o zmianę stanowiska przyjętego w sprawie Taricco I. Argumentacja sądu pytającego w istotnej części opierała się na uznaniu włoskich przepisów dotyczących przedawnienia w sprawach karnych za element włoskiej tożsamości narodowej w rozumieniu art. 4 ust. 2 TFUE ${ }^{42}$. TSUE ostatecznie rozpatrzył pytanie sądu włoskiego pozytywnie w swoim wyroku w sprawie Taricco $I I^{43}$, przyjmując, że unijne prawa podstawowe mogą $\mathrm{w}$ określonych przypadkach ograniczać wymóg zapewnienia skutecznej ochrony finansom Unii (nie odwołując się jednak wprost do art. 4 ust. 2 TUE). W odpowiedzi w swoim kończącym sprawę orzeczeniu 115/2018 włoski Trybunał Konstytucyjny wydał orzeczenie określające dokładnie skutki wyroku Taricco $I$ we włoskim systemie prawnym ${ }^{44}$, w pewien sposób uzurpując sobie kompetencje w zakresie określania zakresu skuteczności prawa unijnego (Amalfitano, Pollicino 2018).

Powyższa konstelacja pod wieloma względami przypomina sytuację stojącą u podstaw orzeczenia Identitätskontrolle. Przede wszystkim dotyczyła ona również zabezpieczenia krajowych praw podstawowych w kontekście pierwszeństwa prawa UE. Dodatkowo dotyczyła sytuacji, w której krajowe orzecznictwo i praktyka były krytyczne wobec decyzji podjętych przez TSUE i wyrażały gotowość ich obejścia (Dovhań 2018). Ponadto, podobnie jak miało to miejsce w kontekście niemieckim, doświadczenia sądu krajowego związane z wcześniejszymi próbami zadania pytania prejudycjalnego nie były zachęcające (zignorowanie pozycji krajowej w sprawie Taricco I). Wreszcie podobny był finał

${ }^{41}$ Wyrok TSUE z 8 września 2015 r. w sprawie C-105/14 Taricco I.

${ }^{42}$ Decyzja dostępna: https://www.cortecostituzionale.it/documenti/download/doc/recent_ judgments/O_24_2017.pdf [dostęp 10.06.2018].

${ }^{43}$ Wyrok TSUE z 5 grudnia 2017 r. w sprawie C-42/17 Taricco II.

${ }^{44}$ Decyzja dostępna: https://www.cortecostituzionale.it/documenti/comunicatistampa/CC_ CS_20180601103714.pdf [dostęp 10.06.2018]. 
obydwu interakcji - poszerzenie przestrzeni sądów krajowych do zapewniania skuteczności prawom podstawowym. Obydwa sądy doszły jednak do pożądanego rozstrzygnięcia odmiennymi drogami - sąd włoski wybrał rozwiązanie w większym stopniu odwołujące się do stworzonych przez prawo UE mechanizmów dialogu. Po pierwsze zdecydował się na zadanie pytania prejudycjalnego, po drugie zaprezentował swoje argumenty za pośrednictwem unijnego „wehikułu”, tj. pojęcia tożsamości narodowej. Z drugiej jednak strony, nie można zapominać, że w tle majaczyła groźba zastosowania przez włoski Trybunał Konstytucyjny zasady pierwszeństwa konstytucji, co pozwala postawić pytanie, czy tak naprawdę różnica pomiędzy obiema sytuacjami nie dotyczyła bardziej formy niż treści.

W tym miejscu warto tylko zaznaczyć, że ani TSUE, ani Rzecznik Generalny Bot w swojej opinii z 18 lipca 2017 r., ani wreszcie włoski Trybunał Konstytucyjny nie odwołały się do orzeczenia Identitätskontrolle. Skłania to do postawienia sobie pytania, czy bez wcześniejszego wyroku FSK TSUE doszedłby do tych samych konkluzji i zmienił, wbrew wnioskom Rzecznika Generalnego, poglądy sformułowane wcześniej w wyroku Taricco I. Okoliczność, że również w sprawie Aranyosi i Căldăraru TSUE nie wspomniał nawet słowem o wyroku FSK, uprawdopodobniałaby taką interpretację. Można przypuszczać, że okoliczność, iż FSK de facto skorzystał z możliwości kontroli tożsamości konstytucyjnej, wymuszając na TSUE korektę wcześniejszego orzecznictwa, miała wpływ także na jego bardziej ugodową postawę wobec włoskiego Trybunału Konstytucyjnego wyrażoną przez orzeczenie Taricco II.

\subsection{FSK - jednak nie samotna wyspa?}

Jak się wydaje, z powyższych rozważań można wysnuć wniosek, że schemat interakcji wykazany przez FSK w orzeczeniu 2 BvR 2735/14 pod wieloma względami przypomina przebieg interakcji pomiędzy ETPC i TSUE w sprawach azylowych. Pewnych analogii można dopatrywać się zarówno w wyjściowych intencjach obydwu sądów, jak również w skutkach ich działań, mianowicie wymuszeniu porzucenia pewnej linii orzeczniczej przez TSUE. W tym sensie orzeczenie FSK stanowiłoby potwierdzenie tezy o „ściśnięciu” TSUE pomiędzy Strasburgiem i Karlsruhe (Reestman, Besselink 2016). Dodatkowo, w świetle wspomnianej już historii interakcji pomiędzy obydwoma sądami europejskimi, pewne ograniczenie unijnej zasady zaufania na rzecz praw podstawowych gwarantowanych na innym poziomie systemu prawnego wygląda już jako coś mniej wyjątkowego.

Trochę odmiennie prezentuje się kwestia wyroku FSK w kontekście orzecznictwa innych sądów konstytucyjnych. Jak się wydaje, trudno porównywać postanowienie Identitätskontrolle z orzecznictwem czeskiego trybunału dotyczącym Stowackich Emerytur. Wprawdzie FSK nie posunął się do formalnego stwierdzenia 
sprzeczności pomiędzy konstytucją a prawem UE, nie zrywając dialogu, w istocie jednak, samą groźbą zmaterializowania się takiego wariantu, wymógł na TSUE systemową korektę orzecznictwa w sprawach ENA, dla której podstawą był wyrok w sprawie Aranyosi. Wnioski płynące z sagi Taricco mogłyby sugerować, że FSK mógł osiągnąć zamierzony efekt w sposób bardziej koncyliacyjny, w większym stopniu szanujący mechanizmy dialogu sądowego wypracowane na gruncie prawa UE, zadając pytania prejudycjalne i zamiast do krajowej tożsamości konstytucyjnej, odwołując się do unijnego pojęcia tożsamości narodowej. Można jednak wyrazić pewną wątpliwość, czy wyrok TSUE Taricco $I^{45}$ byłby możliwy, gdyby nie wcześniejsze orzeczenie Identitätskontrolle.

W tej konstelacji najbardziej problematyczny jest przykład węgierski. Jak się wydaje, orzeczenie węgierskiego Trybunału Konstytucyjnego odwołujące się do tożsamości konstytucyjnej (i wspierające się przy tym omawianym orzeczeniem FSK) miało na celu raczej uniemożliwienie realizacji celu aktu prawa unijnego z racji jego niekonstytucyjności, aniżeli wymuszenie na TSUE (lub innych instytucjach unijnych) pewnej korekty ich działań. W tym sensie materializowało ono lęki związane z doktryną counter-limits, mianowicie zaistnienie stanu realnej sprzeczności pomiędzy prawem unijnym a krajowym. Sugerowałoby ono, że zasady sformułowane w orzeczeniu FSK mogłyby być przynajmniej potencjalnie bardzo niebezpieczne dla spójności prawa europejskiego. $Z$ drugiej jednak strony można również twierdzić, że, przez porównanie, w znacznej mierze bezkompromisowy charakter orzeczenia węgierskiego pokazuje, iż FSK w swoim orzeczeniu zachował jednak pewną otwartość wobec sądu unijnego.

Podsumowując, należy stwierdzić, że analiza porównawcza nie prowadzi do zasadniczej zmiany postawionych wyżej wniosków co do rozumienia decyzji FSK jako zdecydowanego głosu krajowego sądu konstytucyjnego na rzecz ochrony krajowych praw podstawowych, wyrażanego jednak w akceptowalnych z punktu widzenia europejskiej wspólnoty prawnej ramach dialogu międzysądowego. Decyzja FSK z całą pewnością była radykalna i zaowocowała istotną korektą orzecznictwa ze strony TSUE, pod tym względem widać jednak daleko posuniętą analogię względem wcześniejszych działań ETPC przy okazji wyroku w sprawie M.S.S. przeciwko Belgii i Grecji. Prima facie wydawałoby się, że może bardziej optymalne byłoby zastosowanie łagodniejszego rozwiązania włoskiego, pozostaje jednak wątpliwość, czy w danej sytuacji mogłoby ono doprowadzić do analogicznych rezultatów. Porównanie ze sprawą węgierską z drugiej strony pokazuje, że dokonując rozstrzygnięcia, FSK działał w sposób ostrożny i wyważony, uzyskując pożądany przez siebie skutek, bez stwierdzania istnienia sprzeczności pomiędzy prawem UE i prawem krajowym.

${ }^{45}$ Wyrok TSUE z 5 grudnia 2017 r. w sprawie C-42/17 Taricco II. 


\section{WNIOSKI}

Orzeczenie niemieckiego FSK w sprawie Identitätskontrolle jest przykładem wykorzystania instytucji dialogu międzysądowego do zapewnienia faktycznego przestrzegania praw podstawowych zawartych w krajowych konstytucjach. Niemiecki sąd w sposób zdecydowany stanął na stanowisku, że niezgodna z UZ RFN jest sytuacja, w której nie ma możliwości wstrzymania wykonalności ENA z powodu naruszania przez konkretny nakaz krajowych praw podstawowych, nie dochodząc jednak do stwierdzenia niezgodności prawa Unii z UZ RFN. Tym samym dał on TSUE szansę na odniesienie się do zaproponowanych wartościowań. TSUE de facto uwzględnił zaproponowane przez FSK rozwiązanie w swoim orzeczeniu w sprawie Aranyosi, ograniczając stosowanie zasady zaufania na rzecz poszerzenia zakresu ochrony unijnych praw podstawowych. Powyższy schemat interakcji stanowi w zasadzie powtórzenie wzorca znanego z wcześniejszej kontrowersji konstytucyjnej pomiędzy TSUE a ETPC dotyczącej zasady wzajemnego zaufania w kontekście spraw azylowych. Novum stanowi tutaj jednak fakt ustąpienia przez TSUE przed sądem krajowym. $Z$ tego punktu widzenia, podobnie jak miało to miejsce w sytuacji interakcji pomiędzy prawem Unii a EKPC, wydaje się, że fakt oparcia się przez TSUE w teście Aranyosi na KPP, interpretowanej analogicznie do niemieckiej konstytucji, nie osłabiło ochrony krajowych praw podstawowych, zmianie bowiem uległa nie ich treść, a przepis, z którego są one wywodzone.

Można zadać sobie pytanie, dlaczego FSK zdecydował się na „szorstką” formę dialogu, zamiast skorzystać, podobnie jak uczynił to sąd włoski w sprawie Taricco II, z oferowanego przez prawo UE pytania prejudycjalnego. Nie ulega wątpliwości, że rozwiązanie takie byłoby pod wieloma względami optymalne. Wydaje się jednak, że FSK miał dość silne podstawy, by wątpić w jego skuteczność, zarówno w świetle restrykcyjnego podejścia TSUE do ograniczania skuteczności prawa UE ze względu na krajowe prawa podstawowe, jak również w świetle niezdefiniowania unijnej „tożsamości narodowej”. Niezależnie od tego można przypuszczać, że również dla samego FSK był to raczej przypadek jednostkowy. Sąd bowiem nie tylko uwzględniał wyrok w sprawie Aranyosi w swoim późniejszym orzecznictwie, ale nie wahał się też zadawać dalszych pytań prejudycjalnych, również w bardzo kontrowersyjnych sprawach (jak sprawa $O M T^{46}$ ). W szczególności fakt ponownego zadania pytania w sprawie wykazującej znaczne podobieństwo do sprawy Gauweiler, rozstrzygniętej przez TSUE nie po myśli trybunału w Karlsruhe, wskazywałoby, że FSK zamierza docelowo podążyć raczej drogą sądu włoskiego, działając z szacunkiem dla mechanizmów dialogu gwarantowanych przez prawo UE. Tym samym, w pewnym sensie, można mówić o jedynie „korygującej” funkcji orzeczenia FSK.

${ }^{46}$ Postanowienie FSK z 14 stycznia 2014 r. w sprawie 2 BvR 2728/13 OMT, https://www.bundesverfassungsgericht.de/SharedDocs/Entscheidungen/DE/2014/01/rs20140114_2bvr272813.html. 
W tym miejscu można postawić pytanie, na ile wzorzec interakcji sformułowany przez FSK może wpływać na dalszy rozwój dialogu sądowego w UE? Jak się wydaje, wskazany w tym orzeczeniu model interakcji zasadniczo ma pewien potencjał i dostarcza inspiracji dla modeli ochrony własnych praw podstawowych. Można zaryzykować postawienie hipotezy, że wyrok Taricco II jest w pewnym sensie pokłosiem orzeczenia Identitätskontrolle, które mogło z jednej strony zachęcać włoski sąd konstytucyjny do zadania pytania, z drugiej - czynić TSUE bardziej skłonnym do zmiany wcześniejszego stanowiska. Z innej strony jednak, jak pokazuje wyrok węgierski, zawarte w omawianym postanowieniu FSK wartościowania mogą zostać wykorzystane również do poparcia tezy o niestosowaniu prawa UE w związku z jego sprzecznością z konstytucją. Sprawa węgierska dotyczyła porozumienia międzyrządowego, w związku z czym nie zrodziła zasadniczych problemów dla sądów krajowych mających za zadanie rozstrzygać pojedyncze zawisłe przed nimi sprawy. Wydaje się jednak, że gdyby dotyczyła ona spraw znajdujących się zasadniczo w kognicji sądów powszechnych, to mogłaby skutkować rozbieżnościami w orzecznictwie, spowodowanymi odmienną percepcją treści i obowiązywania prawa UE przez krajowy trybunał konstytucyjny i TSUE. Wreszcie nie można zapominać o skutkach ograniczenia zastosowania zasady wzajemnego zaufania dla funkcjonowania instrumentów z zakresu współpracy w dziedzinie wymiaru sprawiedliwości, przyczyniających się zarówno do kryzysu systemu azylowego, jak również ENA. Jak bardzo mogą one być dalekosiężne, pokazuje sprawa LM versus Secretary of State ${ }^{47}$, gdzie wyjątki od automatyzmu wykonywania ENA wypracowane w orzeczeniu Aranyosi (będącym konsekwencją wydania orzeczenia w sprawie Identitätskontrolle) mogą prowadzić do ograniczenia automatyzmu stosowania ENA wystawianego przez polskie sądy, tym samym podkopując efektywne funkcjonowanie wspólnego obszaru prawnego. Dokonanie właściwego wyważenia pomiędzy ochroną praw podstawowych a funkcjonowaniem danego reżimu prawnego wykracza już jednak poza ramy niniejszego studium.

\section{BIBLIOGRAFIA}

Amalfitano, Chiara, Oreste Pollicino. 2018. Two Courts, two Languages? The Taricco Saga Ends on a Worrying Note, https://verfassungsblog.de/two-courts-two-languages-the-taricco-saga-ends-on-a-worrying-note/, post z 6 czerwca 2018 r. [dostęp 10.06.2018].

Anagnostaras, Georgios. 2016. "Mutual confidence is not blind trust! Fundamental rights protection and the execution of the European Arrest Warrant: Aranyosi and Caldararu", Common Market Law Review 53: 1675-1704.

${ }^{47}$ Wyrok TSUE z 25 lipca 2018 r. w sprawie C-216/18 LM versus Secretary of State. 
Bárd, Petra. 2018. "Saving EU Criminal Justice Proposal for EU-wide supervision of the rule of law and fundamental rights". CEPS Papers in Liberty and Security in Europe 1: 1-25.

Bogdandy Von, Armin, Stephan Schill. 2017. „Artikel 4 EUV”. W Das Recht der Europäischen Union. Red. Eberhard Grabitz, Meinhard Hilf, Martin Nettesheim. München: C.H. Beck.

Burchardt, Dana. 2016 „Die Ausübung der Identitätskontrolle durch das Bundesverfassungsgericht". Zeitschrift für ausländisches öffentliches Recht und Völkerrecht 76: 527-551.

Callies, Christian. 2016. „Artikel 24 abs. 1”. W Grundgesetz. Kommentar. Red. Theodor Maunz, Günter Dürig et al. München: C.H. Beck.

Cloots, Elke. 2015. National Identity in EU Law. Oxford University Press.

Dovhań, Halyna. 2018. „Tożsamość konstytucyjna w acquis constitutionnel Sądu Konstytucyjnego Republiki Włoskiej: sprawa Taricco”. Europejski Przegląd Sąowy 7: 11-20.

Golecki, Mariusz Jerzy. 2015. „Judicial Dialogue and the New Doctrine of Constitutional Sovereignty in Judgments of Central European Constitutional Courts". W IX World Congress of Constitutional Law (Oslo, 16-20 June 2014). Contributions by Polish Scholars. Red. Krzysztof Budzidło. Warszawa: Wydawnictwo Trybunału Konstytucyjnego.

Halmai, Gabor. 2017. Constitutional Court Decision on the Hungarian Government's Constitutional Identity Defence, https://blogs.eui.eu/constitutionalism-politics-working-group/constitutional-court-decison-hungarian-governments-constitutional-identity-defense/, 17 stycznia [dostęp 10.06.2018].

Hillgruber, Christian, Christoph Goos. 2011. Verfassungsprozessrecht. Wyd. 3. Heidelberg: CF Müller.

Koncewicz, Tadeusz Tomasz. 2015. „Constitutional Identity in the European Legal Space and the Comity of Circumspect Constitutional Courts”. Gdańskie Studia Prawnicze 33: 195-215.

Krämer, Rike, Judith Janna Märten. 2015. „Der Dialog der Gerichte - die Fortentwicklung des Persönlichkeitsschutzes im europäischen Mehrebensystem”. Europarecht 2: 169-189.

Lang, Andrej. 2018. „National Courts ultra vires review of the ECB's policy of quantitative easing: An analysis of the German Constitutional Court's preliminary reference order in the PSPP case". Common Market Law Review 55: 923-951.

Lenaerts, Koen. 2017. „La vie après l'avis: Exploring the principle of mutual (yet not blind) trust”. Common Market Law Review 54: 805-840.

Lenaerts, Koen, Ignace Maselis, Kathleen Gutman. 2014. EU Procedural Law. Oxford University Press.

Mei van der, Anne Pieter. 2017. „The European Arrest Warrant system. Recent developments in the case law of the Court of Justice". Maastricht Journal of European and Comparative Law 24: 882-904.

Nowag, Julian. 2016. „EU Law, Constitutional Identity, and Human Dignity: A Toxic Mix?”. Common Market Law Review 54: 1441-1454.

Ostropolski, Tomasz. 2016. „Naruszenie praw podstawowych jako przesłanka odmowy wykonania ENA - uwagi do wyroku Trybunału Sprawiedliwości z 5.04.2016 r. w sprawach połączonych C-404/15 Aranyosi i C-659/15 PPU Căldăraru”. Europejski Przegląd Sądowy 11: 20-26.

Reestman, Jan-Herman, Leonard Besselink. 2016. „Sandwiched Between Strasbourg and Karlsruhe: EU Fundamental Rights Protection”. European Constitutional Law Review 16: 213-222.

Schima, Bernhard. 2015. Das Vorabentscheidungsverfahren vor dem EuGH. Unter besonderer Berücksichtigung der Rechtslage in Österreich und Deutschland. Mainz: C.H. Beck.

Skomerska-Muchowska, Izabela. 2018. „The Dialogue of CEE Constitutional Courts in the Era of Constitutional Pluralism". W Transnational Judicial Dialogue on International Law in Central and Eastern Europe. Red. Anna Wyrozumska. Lódź: Wydawnictwo Uniwersytetu Łódzkiego. 
Staśkiewicz, Wiesław (red.). 2011. Konstytucje państw europejskich. Warszawa: Wydawnictwo Sejmowe.

Taborowski, Maciej. 2016. „Znaczenie art. 53 Karty Praw Podstawowych Unii Europejskiej dla poziomu ochrony praw podstawowych w krajowym prawie konstytucyjnym". Państwo i Prawo 70: $40-57$.

Bartosz Soloch

\title{
HOW TO PROTECT THE FUNDAMENTAL RIGHTS OF OWN CITIZENS IN THE SITUATION OF THE EU LAW PREDOMINANCE? \\ SOME REFLECTION BASED ON THE CASE LAW OF FCC AND EU COURT OF JUSTICE CONCERNING THE EUROPEAN ARREST WARRANT (EAW)
}

\begin{abstract}
The decision of the German Federal Constitutional Court of December 14, 2015 in the Identitätskontrolle case is crucial for understanding the limits of the possibility to protect national fundamental rights in the European Union. FCC de facto carried out a review of compliance with the obligation under European Union law to unconditionally execute the European Arrest Warrant (EAW) with constitutional guarantees to protect the right to dignity, but ultimately concluded that constitutional guarantees essentially coincide with the EU provisions. When issuing its ruling, although it was clearly different from the EU CJ case law on EAW, the FCC stated that there is no need to ask a question for a preliminary ruling. In spite of this, the ruling clearly influenced the subsequent development of the EU CJ case law, above all, the Aranyosi and Căldăraru cases. Moreover, it seems that it has also significantly influenced the further dynamics of relations between national constitutional courts and the EU CJ in the field of protection of fundamental rights. It can even be said that it is crucial for understanding the dynamics of the process of a judicial dialogue within the EU.
\end{abstract}

Keywords: constitutional identity, identity control, dialogue between courts, fundamental rights, multicentric system. 